\title{
The reverse cholesterol transport system as a potential mediator of luteolysis in the primate corpus luteum
}

\author{
Randy L Bogan ${ }^{2}$ and Jon D Hennebold ${ }^{1,2}$ \\ ${ }^{1}$ Division of Reproductive Sciences, Oregon National Primate Research Center, Oregon Health and Science \\ University, West Campus, 505 Northwest 185th Avenue, Beaverton, Oregon 97006, USA and \\ ${ }^{2}$ Department of Obstetrics and Gynecology, Oregon Health and Science University, Portland, Oregon 97239, USA
}

Correspondence should be addressed to J D Hennebold at Division of Reproductive Sciences, Oregon National Primate Research Center, Oregon Health and Science University; Email: henneboj@ohsu.edu

\begin{abstract}
The cessation of progesterone $\left(\mathrm{P}_{4}\right)$ production (i.e. functional regression), arguably the key event in luteolysis of the primate corpus luteum (CL), is poorly understood. Previously, we found that genes encoding proteins involved in cholesterol uptake decreased, while those involved in cholesterol efflux (reverse cholesterol transport, RCT) increased in expression during spontaneous functional regression of the rhesus macaque $\mathrm{CL}$, thereby potentially depleting the cholesterol reserves needed for steroidogenesis. Therefore, a comprehensive analysis of the components necessary for RCT was performed. RCT components were expressed (mRNA and/or protein) in the macaque $C L$ including cholesterol sensors (liver $X$ receptors $\alpha$ or NR1H3; and $\beta$ or NR1H2), efflux proteins (ATP-binding cassette subfamilies A1 (ABCA1) and G1), acceptors (apolipoproteins A1 or APOA1; and E or APOE), and plasma proteins facilitating high-density lipoprotein formation (lecithin:cholesterol acyltransferase or LCAT; phospholipid transfer protein or PLTP). ABCA1, APOE, PLTP, and NR1H3 increased, while lipoprotein receptors decreased, in expression (mRNA and/or protein) through the period of functional regression. The expression of $A P O A 1$ and $A P O E$, as well as $N R 1 H 3$, was greatest in the $C L$ and tissues involved in regulating cholesterol homeostasis. Immunolocalization studies revealed that RCT proteins and lipoprotein receptors were expressed in large luteal cells, which possess intracellular cholesterol reserves during periods of $\mathbf{P}_{\mathbf{4}}$ synthesis. Lipid staining revealed changes in luteal cholesterol ester/lipid distribution that occurred following functional regression. These results indicate that decreased cholesterol uptake and increased RCT may be critical for the initiation of primate luteolysis by limiting intracellular cholesterol pools required for steroidogenesis.
\end{abstract}

Reproduction (2010) 139 163-176

\section{Introduction}

The corpus luteum $(\mathrm{CL})$ produces progesterone $\left(\mathrm{P}_{4}\right)$ during the luteal phase of the menstrual cycle, and $\mathrm{P}_{4}$ is absolutely required to maintain early pregnancy in primates. However, in nonconception cycles, $\mathrm{P}_{4}$ secretion from the $\mathrm{CL}$ must cease to allow for the initiation of the next ovarian cycle. Therefore, understanding the factors controlling CL regression (luteolysis) is of considerable importance. Luteolysis occurs in two phases: 1) a decrease in $\mathrm{P}_{4}$ synthesis (functional regression), and 2) degradation and structural remodeling of the CL (structural regression; Hoyer 1998, Stouffer 2003). Functional regression must occur before structural regression can proceed due to the luteoprotective effects of $\mathrm{P}_{4}$ (Hoyer 1998, Stouffer 2003). However, the molecular processes responsible for initiation of functional regression and subsequent structural regression in the primate $\mathrm{CL}$ are poorly defined.
Functional regression in primates is characterized by reduced sensitivity to $\mathrm{LH}$ as the $\mathrm{CL}$ ages (Cameron \& Stouffer 1982, Eyster et al. 1985, Brannian \& Stouffer 1991), and pulses of LH must increase or a more potent LH-receptor ligand (chorionic gonadotropin) must be present to maintain the primate $\mathrm{CL}$ by the end of the normal luteal phase (Duffy et al. 1999). The mechanisms responsible for the loss of $\mathrm{P}_{4}$ synthesis in an $\mathrm{LH}$-replete environment are not known. To address this void in our understanding of primate luteolysis, we previously used a microarray approach to identify global changes in gene expression occurring throughout the normal period of functional regression in the primate $\mathrm{CL}$ (Bogan etal. 2009). From the resultant database, it was noted that genes whose products are involved in cholesterol uptake (low-density lipoprotein receptor or $L D L R$; scavenger receptor type $\mathrm{B}$ class 1 or SCARB1) decreased in expression, while ATPbinding cassette subfamilies $\mathrm{A} 1$ and $\mathrm{G} 1$ ( $A B C A 1$ and $A B C G 1)$ increased during the approximate time when 
functional regression occurred. ABCA1 and ABCG1 are two key cholesterol efflux proteins critical for reverse cholesterol transport (RCT), a process whereby excess cholesterol is removed from cells and transported to the liver for elimination as bile or bile acids (Mahley et al. 2006). Because steroid hormones are derived from cholesterol, induction of RCT coupled with inhibiting extracellular cholesterol uptake could conceivably cause functional regression in the $\mathrm{CL}$ by limiting the substrate necessary for steroidogenesis.

In addition to $A B C A 1$ and $A B C G 1$, the RCT system requires coordination of many proteins including cholesterol sensors (NR1H3/LXR $\alpha$ and NR1H2/LXR $\beta$ ), cholesterol acceptors (apolipoproteins A1 (APOA1) and $\mathrm{E}(\mathrm{APOE}))$, and plasma proteins facilitating high-density lipoprotein (HDL) formation (lecithin:cholesterol acyltransferase (LCAT), phospholipid transfer protein (PLTP), and cholesteryl ester transfer protein (CETP)). Unesterified cholesterol and phospholipids are transferred to APOA1, the major protein component of HDL, by the $A B C$ transporters (Mahley et al. 2006). The free cholesterol bound to APOA 1 is esterified by LCAT thus changing the morphology of the HDL molecule from discoidal to spherical as cholesterol esters are packaged into its hydrophobic core (Jonas 2000). The actions of LCAT allow more cholesterol to be transferred to the HDL molecule (Jonas 2000). In addition to APOA1, APOE also may be an important cholesterol acceptor in RCT as some subclasses of HDL contain APOE (Mahley et al. 2006). APOE allows for expansion of the cholesterol ester-rich core, thus increasing the cholesterol-carrying capacity of HDL molecules (Mahley et al. 2006). Additionally, APOE is an LDLR ligand and consequently allows HDL clearance via hepatic LDLR and LDLRrelated proteins (Mahley 1988, Zaiou et al. 2000). Other plasma proteins involved in RCT include PLTP, which promotes the formation of pre- $\beta \mathrm{HDL}$ and thus increases the cholesterol-accepting capacity of plasma (Von Eckardstein et al. 1996, Dullaart \& Van Tol 2001), and CETP, which transfers cholesterol esters from HDL to APOB-containing lipoproteins (low- or very low-density lipoproteins; Mahley et al. 2006).

$\mathrm{NR} 1 \mathrm{H} 2$ and $\mathrm{NR} 1 \mathrm{H} 3$ are known to stimulate transcription of several important RCT genes including ABCA1, ABCG1, PLTP, CETP (Lund et al. 2003) and APOE (Laffitte et al. 2001a), as well as autoregulation of NR1H3 (Laffitte et al. 2001b). They were originally identified as orphan nuclear receptors belonging to the steroid hormone receptor superfamily. They are now known to bind various oxysterols thereby serving as 'cholesterol sensors' that will stimulate RCT in cases of cholesterol excess (Wojcicka et al. 2007).

To our knowledge, the presence and functionality of the RCT system in the CL have not been addressed in any species. Based on our previous genomic analysis of macaque luteal tissue obtained through the period of functional regression (Gene Expression Omnibus accession number GSE12807; Bogan et al. 2009), the RCT system may be induced within the primate $\mathrm{CL}$ to facilitate the loss in $\mathrm{P}_{4}$-producing capacity at the end of nonconception cycles. To this end, the objectives of the current study are to: 1 ) extend our previous findings of differential mRNA expression of ABCA1 and ABCG1, as well as the lipoprotein receptors LDLR and SCARB1 (Bogan et al. 2009), by determining whether their corresponding protein levels are also differentially expressed throughout the normal period of functional regression; 2) determine whether additional components involved in RCT (mRNA or protein) are also expressed in the primate $\mathrm{CL}$ (e.g. APOA1, APOE, LCAT, PLTP, CETP, $\mathrm{NR} 1 \mathrm{H} 2$, and $\mathrm{NR} 1 \mathrm{H} 3$ ); 3) determine the cellular localization of RCT proteins as well as LDLR and SCARB1, protein expression; and 4) assess changes in cholesterol/lipid handling or storage in the primate $\mathrm{CL}$ during its functional regression.

\section{Results \\ Levels of lipoprotein receptor and ABC transporter proteins in the macaque $\boldsymbol{C} \boldsymbol{L}$}

Levels of SCARB1 were not different between mid-late and functional late CL. However, there was a more than threefold decrease from functional to functionally regressed late stage $\mathrm{CL}(P<0.05)$, with SCARB1 being undetectable in very late stage $\mathrm{CL}$ (Fig. 1B). There was an approximately twofold decrease in LDLR from mid-late to functional late $\mathrm{CL}(P<0.05)$, followed by a $>4$-fold decrease from functional to functionally regressed late CL. LDLR was not detected in very late stage CL (Fig. 1B).

Levels of ABCA1 protein were not different between mid-late and functional late $\mathrm{CL}$, but increased by more than twofold from functional to functionally regressed late stage $\mathrm{CL}(P<0.05)$, and continued to rise in the very late stage (Fig. 1C). There were no differences between any groups in levels of ABCG1 protein (Fig. 1C).

\section{Localization of luteal SCARB1, LDLR, ABCA1, and $A B C G 1$}

Large luteal cells stained for SCARB1 while there was minimal or no expression in small cell types such as stroma and endothelial cells (Fig. 2). Pre-absorption of the primary antibody with its immunizing peptide resulted in minimal staining. SCARB1 was evident at the plasma membrane during all stages analyzed. LDLR displayed a similar staining pattern as SCARB1 with the majority of expression occurring in large luteal cells (Fig. 2). Staining for LDLR was evident at the plasma membrane of all stages analyzed, and was absent following pre-absorption of the primary antibody with its immunizing peptide.

ABCA1 expression was observed in large luteal cells, as well as in the endothelial cells and adjacent stroma 

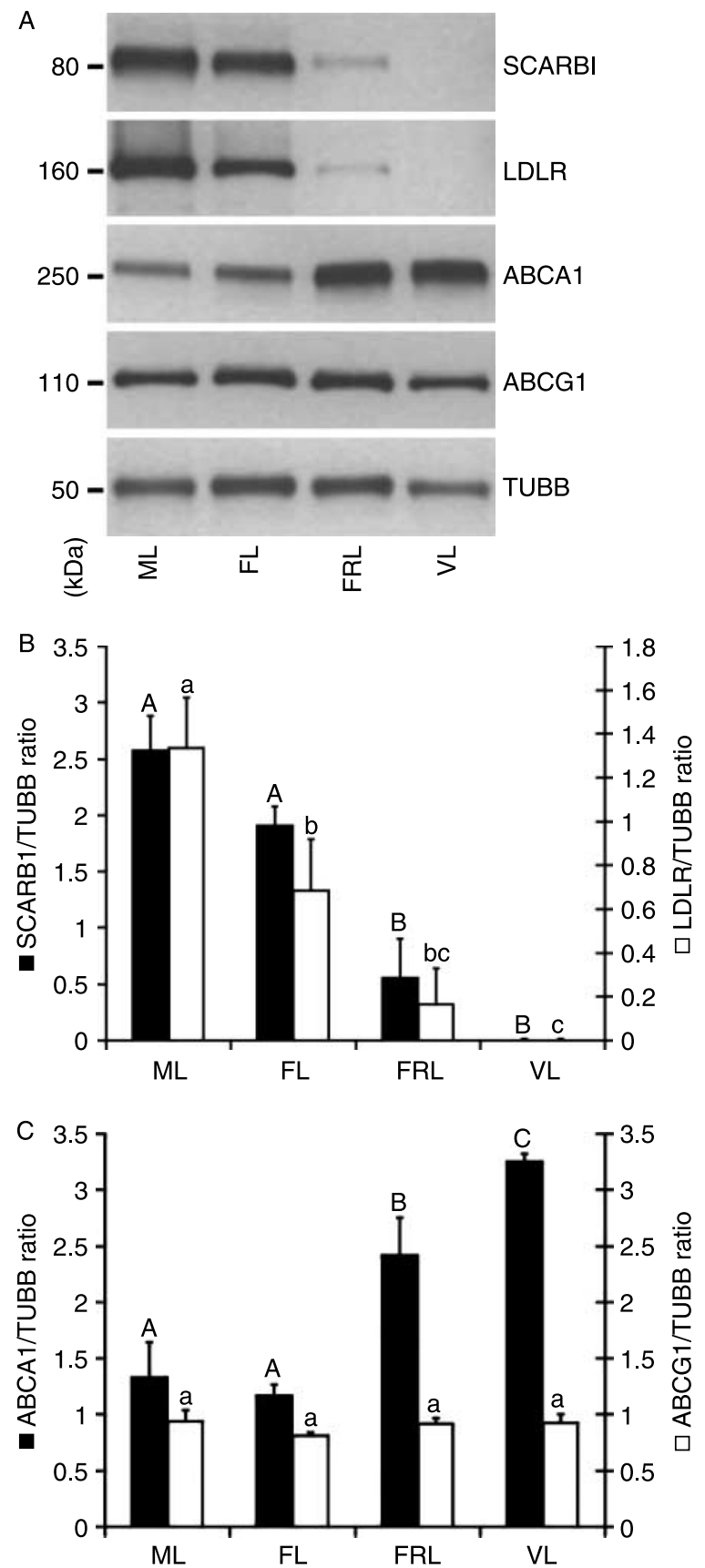

Figure 1 Lipoprotein receptor and $A B C$ transporter protein levels throughout the period of spontaneous functional regression in the rhesus macaque CL. Panel A contains representative western blots for SCARB1, LDLR, ABCA1, ABCG1, and TUBB using samples pooled from $\mathrm{CL}$ collected at either the mid-late $(\mathrm{ML})$, functional late $(\mathrm{FL})$, functionally regressed late $(F R L)$, or very late $(\mathrm{VL})$ stages of the luteal phase. The results of densitometry analyses of individual luteal homogenates ( $n=4 \mathrm{CL} /$ group) for the lipoprotein receptors SCARB1 and LDLR, as well as the cholesterol efflux proteins ABCA1 and ABCG1, are presented in panels $B$ and $C$, respectively. Error bars indicate one S.E.M. Columns with different letters of the same case are significantly different $(P<0.05)$. lining blood vessels (Fig. 2). ABCA1 expression was diffuse throughout the cell in mid-late and functional late $\mathrm{CL}$, while localization near the plasma membrane in some cells was more evident in functionally regressed late CL. ABCG1 expression was also found in large luteal cells, while staining in small luteal cells or near the vasculature was minimal (Fig. 2). During the midlate and functional late stages, ABCG1 expression was predominantly perinuclear with some evidence of plasma membrane staining. In functionally regressed late $\mathrm{CL}$, however, increased plasma membrane localization was observed.

\section{CL expression of APOA1 and APOE}

Both $A P O A 1$ and $A P O E$ mRNA were expressed in the macaque $C L$ at all stages of the luteal phase as determined by GeneChip Operating System (GCOS) absolute expression analysis of microarray data (Bogan et al. 2008a). APOE mRNA levels were lowest in early $\mathrm{CL}$ followed by an increase at each subsequent stage with the exception of a slight decrease between functional and functionally regressed late CL. Quantitative-PCR (Q-PCR) analysis of $A P O E$ expression yielded highly similar results, with the early $C L$ being significantly lower than all other groups $(P<0.05)$ and the functional late and very late $\mathrm{CL}$ being significantly higher $(P<0.05)$ than mid or mid-late CL (Fig. 3A). $A P O A 1$ had a pattern of expression opposite to $A P O E$ as its mRNA levels were highest in the early luteal phase and slowly decreased thereafter with functionally regressed late and very late $\mathrm{CL}$ being significantly lower than all other stages as determined by both microarray and Q-PCR (Fig. 3C).

APOE protein was also detected in the $\mathrm{CL}$ at all stages of the luteal phase by immunohistochemistry (IHC; Fig. 3B). APOE localized to the large luteal cells, with some interspersed staining also noted in stroma and along vessel endothelial cells. APOE staining was primarily observed in the cytoplasm and perinuclear regions of mid and mid-late $\mathrm{CL}$, with a more diffuse pattern observed in functional and functionally regressed late sections. Strong staining for APOA1 was also detected throughout the luteal phase and in all regions of the primate $\mathrm{CL}$ (Fig. 3D). Staining near the plasma membrane of large luteal cells was evident through the functionally regressed late stage, while APOA1 was mostly detected in the cytoplasm of these cells during the very late stage.

\section{CL expression of LCAT, PLTP, and CETP}

LCAT and PLTP mRNA were expressed in the macaque $\mathrm{CL}$ at all stages of the luteal phase as determined by GCOS absolute expression analysis of microarray data (Bogan et al. 2008a). However, CETP mRNA was not detected $(P>0.065)$ in 20 of $24 \mathrm{CL}$, marginally detected 


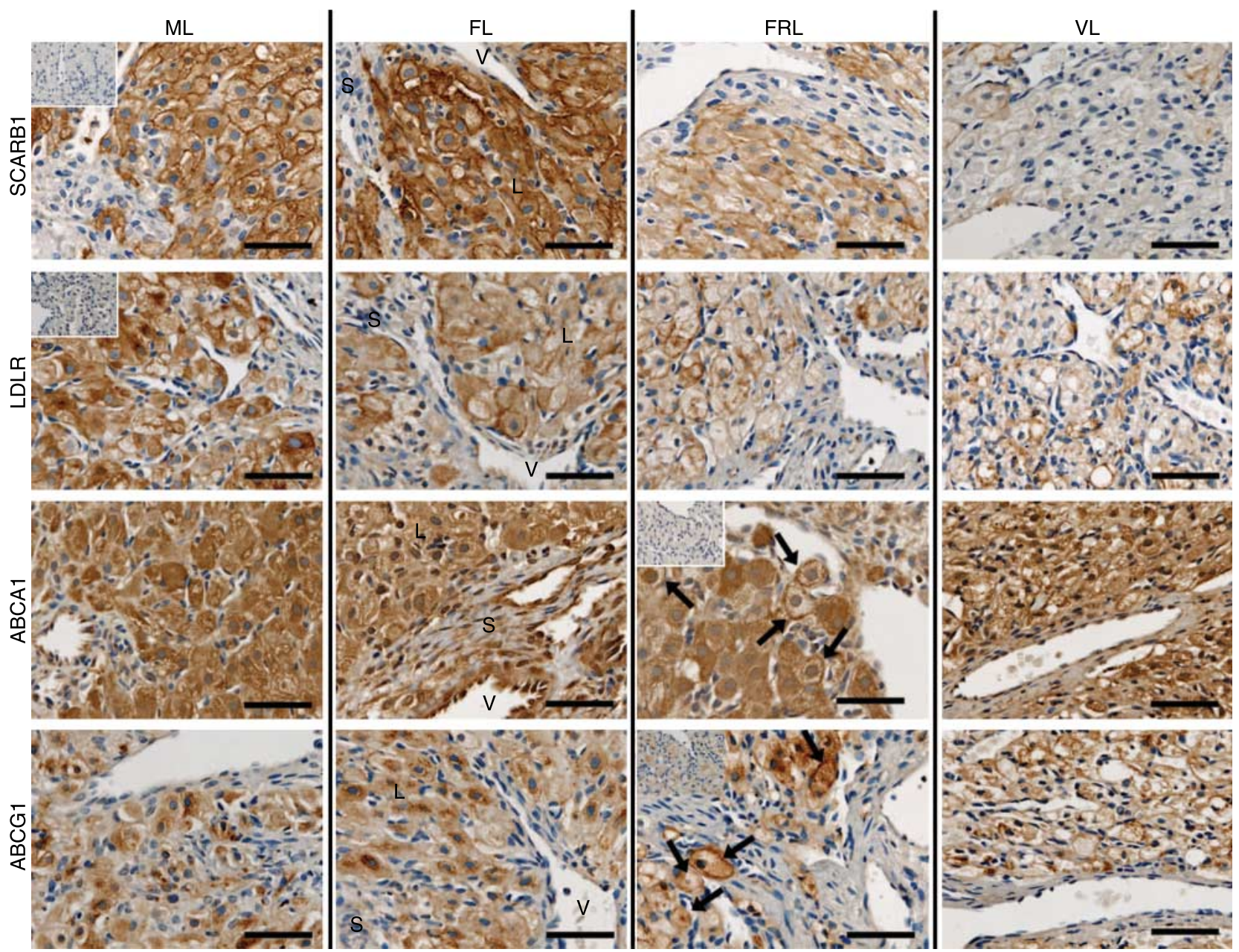

Figure 2 Localization of lipoprotein receptors and $A B C$ transporters in the rhesus macaque $C L$ throughout the period of spontaneous functional regression. Representative photomicrographs of SCARB1, LDLR, ABCA1, and ABCG1 from the mid-late (ML), functional late (FL), functionally regressed late $(\mathrm{FRL})$, and very late $(\mathrm{VL})$ luteal stages are shown. The insets in the upper left corner of the ML samples for SCARB1 and LDLR, as well as in the FRL samples for ABCA1 and ABCG1, are sections that were processed with primary antibody pre-absorbed with immunizing peptide. The approximate locations of various cell types are indicated in the FL panel for each protein and include: large luteal cells (L); small luteal or stromal cells (S); and blood vessels (V). The scale bar in the lower right hand corner of each image is $50 \mu \mathrm{m}$. Arrows indicate the appearance of plasma membrane localization of ABCA1 and ABCG1 in FRL stage CL.

$(0.051>P<0.065)$ in $2 \mathrm{CL}$ (one mid and one functional late), and detected $(P<0.05)$ in only $2 \mathrm{CL}$ (one mid-late and one functionally-regressed late). As CETP mRNA was not detected in the majority of CL collected from all stages of the luteal phase, it does not appear that CETP is expressed by the primate CL.

$L C A T$ was significantly lower in early and very late $C L$ than all other stages $(P<0.05$; Fig. 4A). LCAT expression did not change from mid to functional late stages, while functionally regressed late CL had LCAT levels intermediate of functional late and very late stages $(P<0.05)$. PLTP expression did not change from the early to midlate stages, but increased from the functional late to very late stages (Fig. 4A). The very late $\mathrm{CL}$ had significantly higher levels $(P<0.05)$ of PLTP than all other stages, and functionally regressed late $C L$ were significantly higher $(P<0.05)$ than early to mid-late stages.
LCAT protein was detected within the CL throughout the luteal phase by IHC (Fig. 4B). Cytoplasmic staining for LCAT was noted in large luteal cells, while staining was variable in the stroma. Additionally, LCAT staining was evident in the endothelial cells lining the vasculature. PLTP protein was also present within the $\mathrm{CL}$ (Fig. 4B) and displayed a similar staining pattern as LCAT with expression found primarily in large luteal cells, as well as variable staining in the stroma, and more consistent staining in the regions lining blood vessels.

\section{$C L$ expression of $\mathrm{NR} 1 \mathrm{H} 2$ and $\mathrm{NR} 1 \mathrm{H} 3$}

Both $\mathrm{NR} 1 \mathrm{H} 2$ and $\mathrm{NR} 1 \mathrm{H} 3$ were expressed in the $\mathrm{CL}$ at all stages of the luteal phase as determined by GCOS absolute expression analysis (Bogan et al. 2008a). 


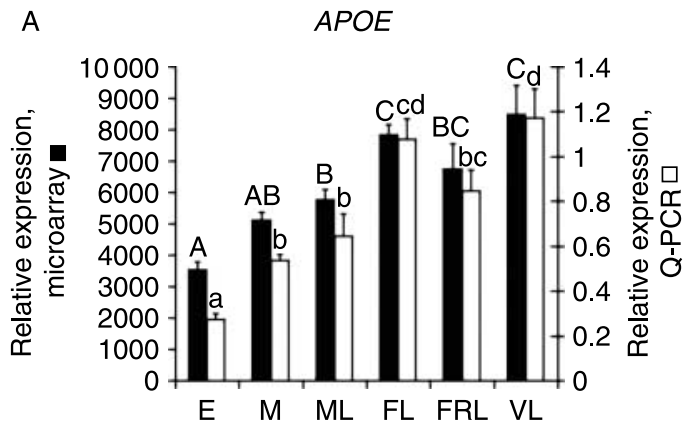

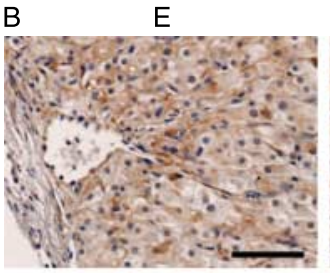
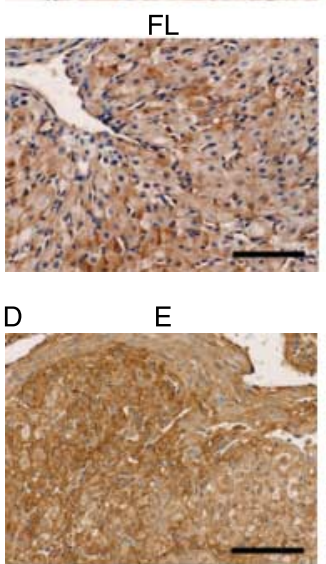

FL

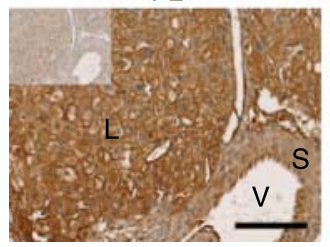

M

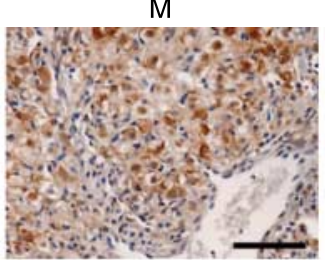

FRL

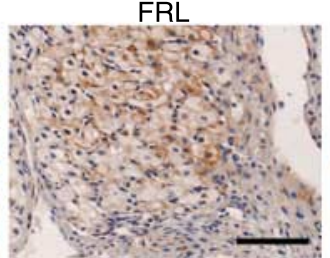

M

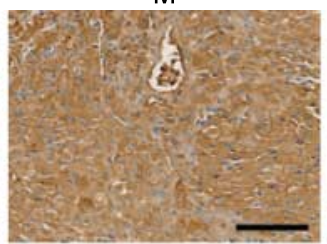

FRL

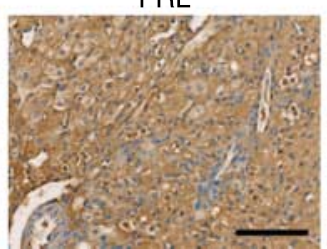

$M L$

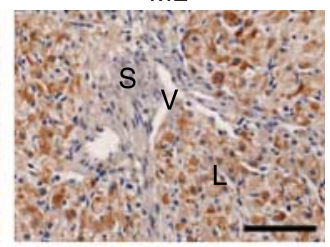

VL

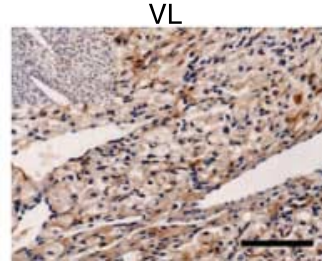

ML

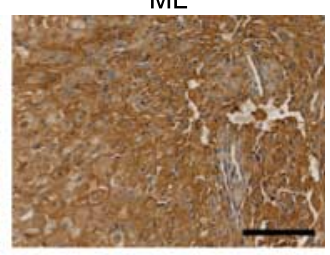

VL

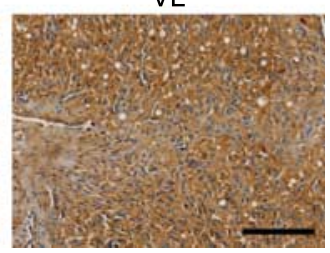

Figure 3 Apolipoprotein expression in the rhesus macaque CL. Panel A contains microarray and Q-PCR expression data for $A P O E$ during the early (E), $\operatorname{mid}(\mathrm{M})$, mid-late $(\mathrm{ML})$, functional late $(\mathrm{FL})$, functionally regressed late $(\mathrm{FRL})$, and very late $(\mathrm{VL})$ stages. Error bars indicate one s.E.M. ( $n=4 \mathrm{CL} / \mathrm{group}$ ). Upper case letters denote significant differences $(P<0.05)$ for microarray data and lower case letters denote significant differences for Q-PCR data. Panel B contains representative photomicrographs for APOE IHC performed using CL obtained from the E to VL stages of the luteal phase. The inset in the upper left corner of the VL sample is from a control section that was probed with primary antibody pre-absorbed with its immunizing peptide. The approximate locations of various cell types are indicated in the ML panel and include: large luteal cells (L); small luteal or stromal cells (S); and blood vessels $(\mathrm{V})$. The scale bar in the lower right hand corner of each image is $100 \mu \mathrm{m}$. Panel C contains microarray and Q-PCR expression data for APOA1 that was analyzed in the same manner as for panel A. Panel D contains representative photomicrographs from APOA1 IHC analysis. The details are similar to the description for panel B except the negative control inset, which is in the FL sample and consists of a control section probed with primary antibody pre-absorbed with purified full-length human APOA1.

Levels of $\mathrm{NR} 1 \mathrm{H} 3(\mathrm{LXR} \alpha)$ did not change from the early to mid-late stages, but significantly increased $(P<0.05)$ by the functional late stage and continued to increase through the very late stage as determined by both microarray and Q-PCR (Fig. 5A). Levels of NR1H2 $(L X R \beta)$ were not different between any groups as determined by microarray. However, Q-PCR analysis of $N R 1 H 2$ expression indicated that, while $N R 1 H 2$ mRNA did not change from the early to mid-late stages, its levels increased from the mid-late to functionally regressed late stages, with functionally regressed late and very late $\mathrm{CL}$ having significantly higher $(P<0.05) \mathrm{NR} 1 \mathrm{H} 2$ levels than early to mid-late stages (Fig. 5A). These changes in $N R 1 H 2$ levels detected by Q-PCR were not due to cross-amplification of $\mathrm{NR} 1 \mathrm{H} 3 \mathrm{CDNA}$ as the primers and probe used were designed within a region unique to rhesus $\mathrm{NR} 1 \mathrm{H} 2$.
Western blot analysis was used to quantify levels of $\mathrm{NR} 1 \mathrm{H} 2$ and $\mathrm{NR} 1 \mathrm{H} 3$ protein during the mid-late to very late stages (Fig. 5B). There were no significant differences between stages in levels of NR1H2. Levels of NR1H3 protein increased by more than threefold from the midlate to functional late luteal phase $(P<0.05)$, with a further increase of more than twofold being detected in very late relative to functionally regressed late $\mathrm{CL}(P<0.05)$.

\section{Localization of NR1H2 and NR1H3}

$\mathrm{NR} 1 \mathrm{H} 2$ protein was detected in the large luteal cells as well as in regions adjacent to the endothelial cells lining blood vessels (Fig. 6). During the mid and mid-late stages, NR1H2 was localized primarily to the cytoplasm of large luteal cells. By the functional late stage, nuclear 
localization of $\mathrm{NR} 1 \mathrm{H} 2$ became evident in large luteal cells and remained present through the functionally regressed late stage. While $\mathrm{NR} 1 \mathrm{H} 2$ protein was still detected in regions of the stroma adjacent to blood vessels during the very late stage, nuclear localization in the large luteal cells was less evident.
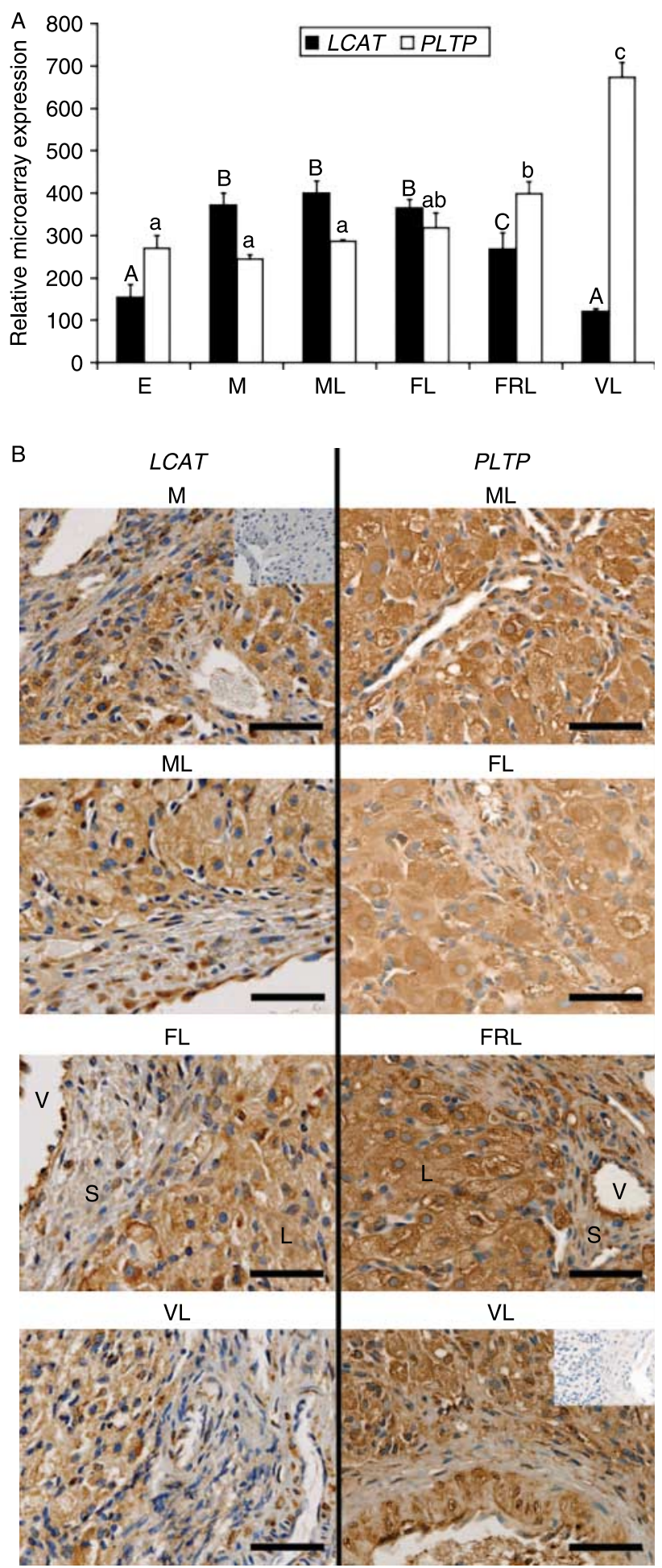

$\mathrm{NR} 1 \mathrm{H} 3$ protein was detected in the same cell types as $\mathrm{NR} 1 \mathrm{H} 2$ including the large luteal cells and regions adjacent to blood vessels (Fig. 6). Staining for NR1H3 in the $\mathrm{CL}$ was weak during the mid-late stage, while nuclear localization of NR1H3 was observed in large luteal cells beginning at the functional late stage. Contrary to $\mathrm{NR} 1 \mathrm{H} 2$, strong nuclear staining of NR1H3 was still apparent in large luteal cells during the very late stage.

\section{Tissue distribution of APOA1, APOE, NR1H2, and NR1H3 mRNA}

APOA1 mRNA levels were greatest in liver, small intestine, and $\mathrm{CL}$, while lower levels were detected in the adrenal, testis, and ovary. There was minimal or nonexistent APOA1 mRNA expression in other tissues analyzed (Fig. 7). APOE mRNA was highly expressed in the $\mathrm{CL}$ with comparatively lower levels present in the other steroidogenic/reproductive tissues analyzed (adrenal, uterus, placenta, testis, and ovary). APOE mRNA was also observed in liver, spleen, kidney, small intestine, colon, hypothalamus, and adipose. $\mathrm{NR} 1 \mathrm{H} 2 \mathrm{was}$ detected in all tissues analyzed except brain; however, the housekeeping control for brain was also weakly amplified. High cycle numbers $(>30)$ were needed to detect $\mathrm{NR} 1 \mathrm{H} 2$ in most tissues. $\mathrm{NR} 1 \mathrm{H} 3$ was expressed in all steroidogenic tissues analyzed, and was especially high in testis and late to very late stage CL. NR1H3 was also highly expressed in liver, spleen, small intestine, and adipose, while heart, lung, lymph node, kidney, stomach, colon, and skeletal muscle displayed lower mRNA levels.

\section{Cholesterol levels and localization}

Cholesterol levels in luteal homogenates increased throughout the luteal phase with functionally regressed and very late stages having significantly higher concentrations of cholesterol $(P<0.05)$ than early or mid $\mathrm{CL}$ (Fig. 8A). During the mid luteal phase, lipid droplets were abundant throughout large luteal cells. However, functionally regressed late $\mathrm{CL}$ were associated with the formation of much larger lipid droplets or aggregates possibly residing in extracellular regions (Fig. 8B).

Figure 4 Expression of proteins that promote $\mathrm{HDL}$ formation in the rhesus macaque $\mathrm{CL}$. Panel A contains microarray expression data for LCAT and PLTP during the early (E), mid (M), mid-late (ML), functional late $(\mathrm{FL})$, functionally regressed late $(\mathrm{FRL})$, and very late $(\mathrm{VL})$ stages of the luteal phase. Error bars indicate one S.E.M. $(n=4$ $\mathrm{CL}$ /group). Columns with different letters of the same case are significantly different $(P<0.05)$. Panel B contains representative photomicrographs for LCAT and PLTP IHC analyses. Insets are control sections where the primary antibody was excluded. The approximate locations of various cell types are indicated in the FL (LCAT) or FRL (PLTP) panels and include: large luteal cells (L); small luteal or stomal cells (S); and blood vessels (V). The scale bar in the lower right hand corner of each image is $50 \mu \mathrm{m}$. 


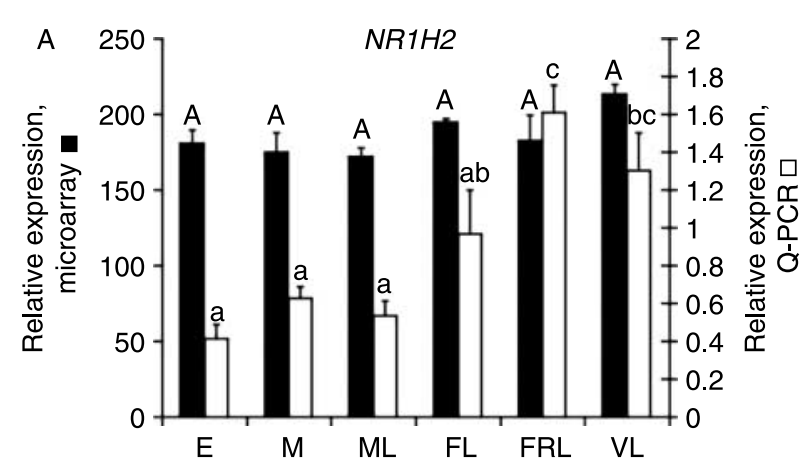

\section{Discussion}

The initial finding that stimulated further research into the RCT system in the CL was based on the divergent patterns of expression between the $A B C$ transporters and lipoprotein receptors during normal functional regression of the primate $\mathrm{CL}$ (Bogan et al. 2009). In the current study, the corresponding protein levels were found to parallel previous mRNA results for $A B C A 1$, SCARB1, and LDLR, but not ABCG1. However, ABCG1 expression was maintained throughout the periods covering functional and structural regression. When considered together, there is clearly an increase in the ratio of $A B C$ transporters to lipoprotein receptors in the primate $C L$ near the time of functional regression. $A B C A 1$ is a full-size $A B C$ transporter (i.e. containing two ATP-binding cassettes and two transmembrane domain regions linked together; Kaminski et al. 2006), which is involved in HDL metabolism by transferring unesterified cholesterol and phospholipids to lipid-free or lipid-poor APOA1 or APOE (Mahley et al. 2006). ABCG1 is a half-size $A B C$ transporter, which has been reported to cooperate with $\mathrm{ABCA} 1$ in cholesterol export by transferring cholesterol to nascent or pre- $\beta$ HDL particles, but not lipid-free APOA1 (Gelissen et al. 2006). In murine macrophages, $A B C A 1$ and ABCG1 are additive with regard to cholesterol efflux (Wang et al. 2007).

Expression of ABCA1, ABCG1, SCARB1, and LDLR was localized primarily to the large luteal cells. These large cells have intracellular cholesterol reserves during the luteal phase, which serve as a substrate for $\mathrm{P}_{4}$ synthesis (Niswender et al. 2000, Stouffer 2006). The high steroidogenic output of the $\mathrm{CL}$, estimated at up to $40 \mathrm{mg}$ of $\mathrm{P}_{4}$ per day in humans (Lipsett 1978), relies primarily on blood-borne cholesterol as de novo synthesis is only important under severely lipid-deprived states (Gwynne \& Strauss 1982, Niswender et al. 2000, Stouffer 2006). Thus, the balance between cholesterol uptake and efflux is likely the primary factor regulating levels of intracellular cholesterol stores. Staining for SCARB1, LDLR, and ABCG1 within the nonsteroidogenic stroma was rarely observed. However, ABCA1 was also frequently expressed in regions adjacent to blood vessels. As expected for cell surface receptors, staining for SCARB1 and LDLR was observed near the plasma membrane at all stages analyzed, although SCARB1 had more pronounced membrane localization. This is likely due to differences in the lipid uptake mechanism between the two receptors as the LDLR works by receptor-mediated endocytosis, which may result in its distribution between the cytoplasm and plasma membrane, whereas SCARB1 works via a selective uptake pathway not involving internalization of the receptor (Glass et al. 1983, Reaven et al. 1984). In contrast, ABCA1 and ABCG1 were primarily expressed in the cytoplasmic and perinuclear regions, with plasma 
membrane staining observed more frequently in functionally regressed late $\mathrm{CL}$. It has been reported that ABCG1 localization is redistributed from intracellular sites to the plasma membrane following treatment with NR1H2/NR1H3 agonists (Wang et al. 2006). Additionally, ABCA1 may be important for intracellular cholesterol movement. ABCA1 expression has been found in

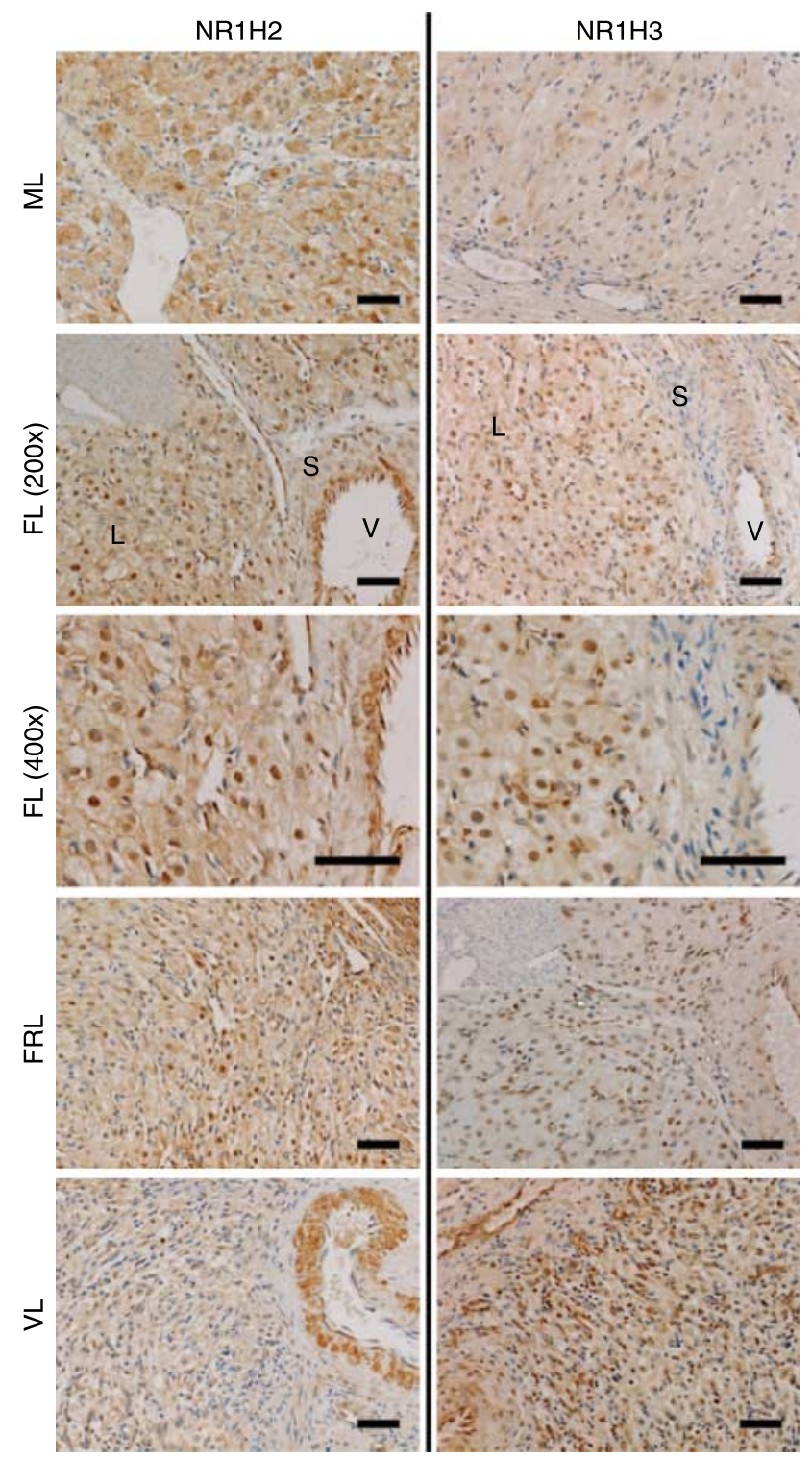

Figure 6 Localization of $\mathrm{NR} 1 \mathrm{H} 2$ and $\mathrm{NR} 1 \mathrm{H} 3$ expression in the rhesus macaque $C L$ throughout the period of spontaneous functional regression. Representative photomicrographs of $\mathrm{NR} 1 \mathrm{H} 2$ and $\mathrm{NR} 1 \mathrm{H} 3$ from the mid-late $(\mathrm{ML})$, functional late $(\mathrm{FL})$, functionally regressed late $(\mathrm{FRL})$, and very late $(\mathrm{VL})$ stages are shown. The insets in the upper left corner of the FL $200 \times$ panel for $\mathrm{NR} 1 \mathrm{H} 2$, and FRL panel for NR1H3, are control sections incubated with primary antibody pre-absorbed with its immunizing peptide $(\mathrm{NR} 1 \mathrm{H} 2)$, or where the primary antibody was excluded (NR1H3). The approximate locations of various cell types are indicated in the FL panel for each protein and include: large luteal cells (L); small luteal or stromal cells (S); and blood vessels (V). The scale bar in the lower right hand corner of each image is $50 \mu \mathrm{m}$. early and late endosomes and lysosomes, the golgi complex, as well as the plasma membrane with trafficking of ABCA1 occurring between these sites (Orso et al. 2000, Neufeld et al. 2001). Certain ABCA1 mutants found in Tangier's disease (familial HDLdeficiency syndrome) fail to redistribute to the plasma membrane (Tanaka et al. 2003), and mice with targeted inactivation of ABCA1 have impaired cellular lipid trafficking via the trans-golgi secretory pathway (Orso et al. 2000). Thus, ABCA1 and ABCG1 redistribution within the cell may be important for RCT and may represent another mechanism whereby RCT is regulated in addition to changes in their expression.

Because apolipoproteins are produced in the liver or other tissues and secreted into the bloodstream, synthesis of apolipoproteins within the CL is not a prerequisite for RCT to occur. However, the overall level of cholesterol efflux may be limited by the amount of apolipoprotein acceptors (Santamarina-Fojo et al. 2001). As the $\mathrm{CL}$ is a highly steroidogenic tissue with large cholesterol reserves (Niswender et al. 2000, Stouffer 2006), intraluteal synthesis of apolipoprotein acceptors may be necessary to support the large amounts of cholesterol that would need to be disposed of during functional regression. Both $A P O A 1$ and $A P O E$ mRNA were expressed throughout the luteal phase, and relative microarray expression units of both genes ranged from $\sim 2300$ up to 8500 , levels several-fold higher than other RCT genes analyzed in the current study. This indicates that the primate $C L$ may synthesize large amounts of lipoproteins that could serve as cholesterol acceptors during RCT. APOA1 expression has been primarily attributed to the liver and small intestine (Yokoyama 2006), which is consistent with our semi-quantitative PCR (SQ-PCR) data. We also detected strong APOA1 expression in the $\mathrm{CL}$, as well as appreciable levels in other steroidogenic tissues including testis, ovary, and adrenal gland. $A P O E$ was more widely expressed than $A P O A 1$, although the $C L$ had $A P O E$ levels higher or comparable to tissues richest in $A P O E$ such as the liver and adipose. While both $A P O A 1$ and $A P O E$ were expressed at high levels throughout the luteal phase, their patterns of expression were nearly opposite as $A P O A 1$ steadily decreased, while $A P O E$ increased from the early to very late stages. This indicates that the two genes are under different transcriptional control in the $\mathrm{CL}$, and rising levels of $A P O E$ may compensate for decreasing APOA1.

APOA 1 and APOE proteins were detected in the $\mathrm{CL}$ by IHC. Because these are circulating proteins, their presence in the $C L$ may be a result of both intraluteal and extraluteal sources, although intracellular staining is likely due to intraluteal synthesis. In steroidogenic tissues, the uptake of cholesterol esters from HDL occurs without internalization of the corresponding lipoproteins (Glass et al. 1983, Reaven et al. 1984) such that nonluteal sources of APOA1 and APOE would likely 

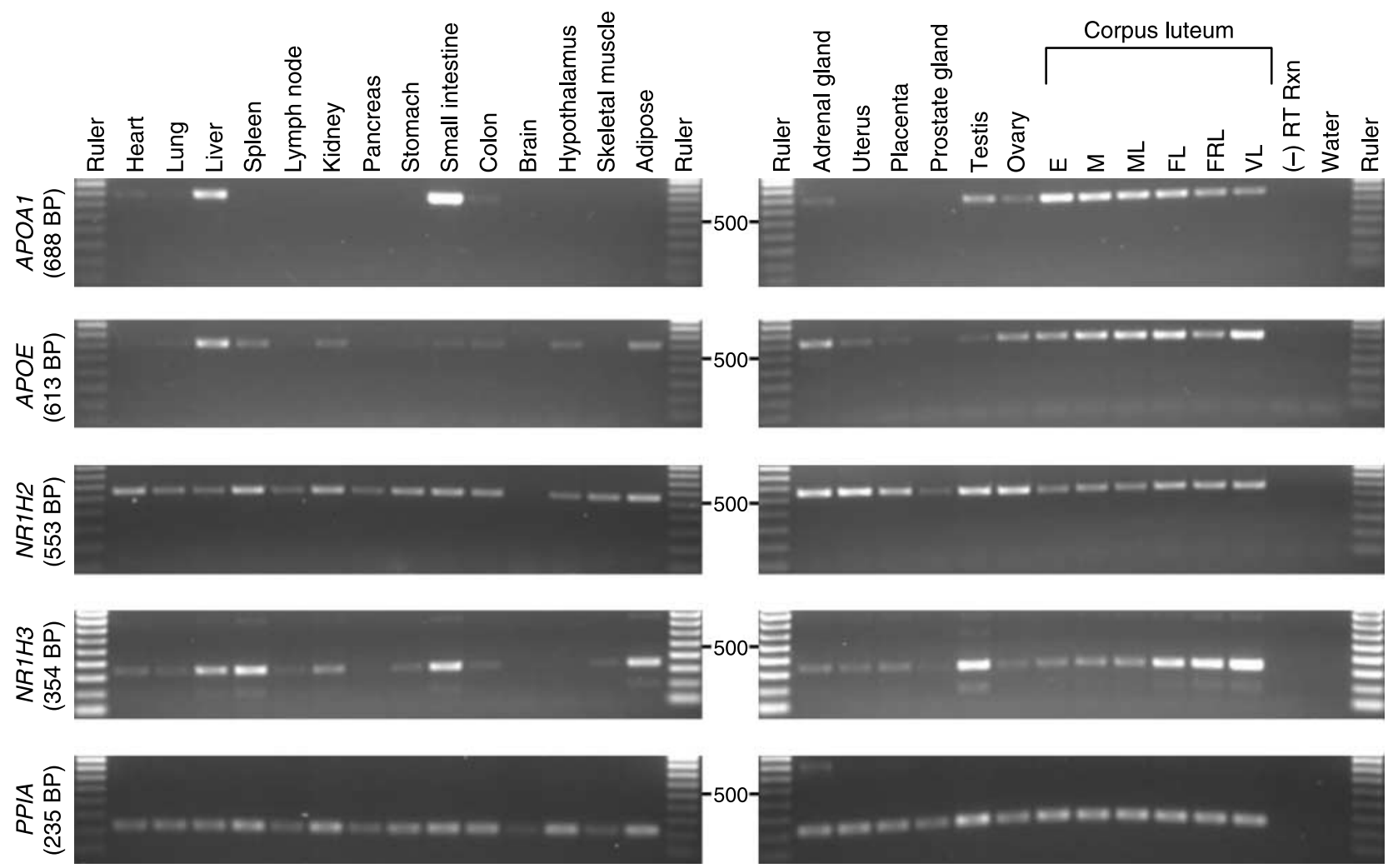

Figure 7 Tissue distribution of $A P O A 1, A P O E, N R 1 H 2$, and $N R 1 H 3$ gene expression in the rhesus macaque. Agarose gel images of PCR amplification products are shown. Gene-specific primers were used to amplify cDNA collected from various rhesus macaque tissues. The number of cycles used in each image is: $A P O A 1=25, A P O E=24, N R 1 H 2=34, N R 1 H 3=26$, and $P P I A=26$. These cycle numbers correspond approximately with the midlinear range of amplification for each gene as determined from pooled luteal cDNA. A 100 bp ruler is included with each image, and the 500 bp band is marked. Expected product size for each gene is indicated.

remain extracellular. APOE was found in large luteal cells, in scattered regions of the stroma, and in the lining of blood vessels. APOE was predominantly localized intracellularly, especially in the perinuclear region during the mid and mid-late stages. By the late stage (functional or functionally regressed), APOE appeared more diffuse throughout the cytoplasm. Intracellular and total luteal staining for APOE was noticeably reduced by the very late stage as compared with the early to functional late stages, which is in contrast to its mRNA levels. Besides the fact that IHC is not a quantitative procedure, there could be a number of reasons for this apparent discrepancy including: 1) APOE mRNA levels do not match its protein levels; 2) the extraluteal contribution to APOE staining is unknown and may be lower in the functionally regressed late to very late stages due to decreased lipoprotein receptor expression; and 3) intraluteal APOE protein synthesis parallels mRNA levels and differences in staining intensity are due to changes in the rate of APOE secretion from luteal cells. The latter possibility is arguably the most probable explanation as the staining pattern observed is consistent with intraluteal synthesis and storage of APOE during periods of high $\mathrm{P}_{4}$ production (mid and mid-late), followed by an enhanced secretion of APOE during functional and structural regression. Strong staining for APOA1 was observed throughout the luteal phase, with a large contribution possibly coming from extraluteal sources. Staining along the plasma membrane was noticed from the early to functionally regressed late stages, possibly due in large part to extracellular APOA1 bound to SCARB1. However, during the very late stage when SCARB1 is virtually absent, APOA1 localization to the plasma membrane was less pronounced while cytoplasmic APOA1 staining remained strong, consistent with intraluteal synthesis.

Similar to the apolipoproteins, luteal expression of LCAT and PLTP is not absolutely required for RCT to occur as they can arrive via the bloodstream from extraluteal sources. However, intraluteal synthesis of these proteins may enhance the efficiency of the RCT system in the CL. Both LCAT and PLTP mRNA were expressed in the CL throughout the luteal phase. Furthermore, both proteins were detected in the $\mathrm{CL}$ by IHC. Intracellular staining was found in large luteal cells. The nonsteroidogenic stroma was mostly devoid of LCAT and PLTP except for small patches of staining. Also, staining was present in regions immediately adjacent to blood vessels. This pattern of expression is consistent with intraluteal synthesis of LCAT and PLTP by large 

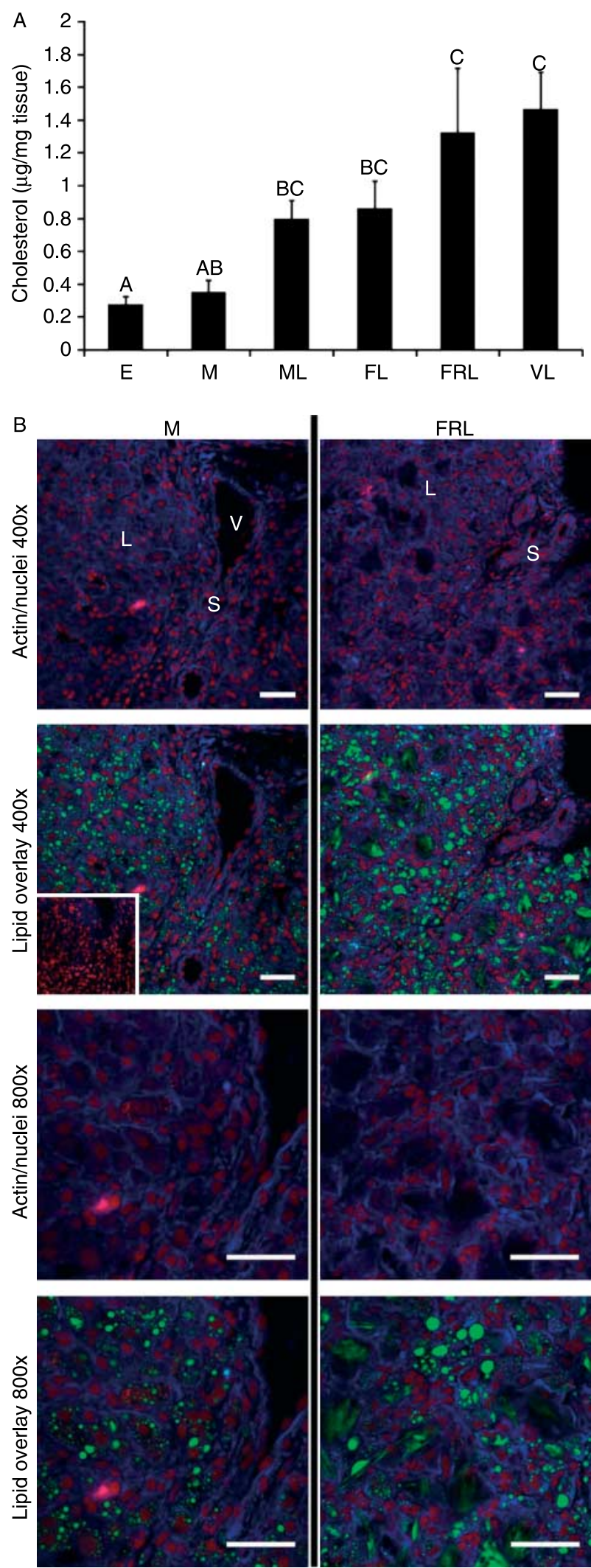

luteal cells, followed by their subsequent secretion. LCAT is functionally dependant on APOA 1 , and to a lesser extent APOE, as LCAT specifically interacts with and is activated by these apolipoproteins (Jonas 2000).

$\mathrm{NR} 1 \mathrm{H} 2$ and $\mathrm{NR} 1 \mathrm{H} 3$ are key regulators of the RCT system. In mice, $N R 1 H 3$ is highly expressed in the liver, intestine, and adipose; but was reported to be present at low or nondetectable levels in steroidogenic tissues such as the adrenal, testis, and ovary (Repa \& Mangelsdorf 2000). Based on our SQ-PCR data, it appears that in the macaque $\mathrm{NR} 1 \mathrm{H} 3$ is also highly expressed in the liver, small intestine, and adipose as was reported in mice. High levels of $\mathrm{NR} 1 \mathrm{H} 3$ were also noted in the macaque spleen, testis, and $\mathrm{CL}$. In contrast, $\mathrm{NR} 1 \mathrm{H} 2$ is ubiquitously expressed in mice (Repa \& Mangelsdorf 2000), which is consistent with our findings in the macaque whereby $N R 1 H 2$ mRNA levels were similar in most tissues. In the macaque $C L$, there was a significant increase in NR1H3 mRNA and protein prior to the drop in serum $\mathrm{P}_{4}$ levels (mid-late to functional late). Both NR1H2 and NR1H3 were expressed within the same cell types of the CL. Their expression within large luteal cells overlaps with the localization of other RCT proteins analyzed in the current study. Genes reported to be transcriptional targets of $\mathrm{NR} 1 \mathrm{H} 2$ and $\mathrm{NR} 1 \mathrm{H} 3$ include: $A B C A 1$, ABCG1, PLTP, and CETP (Lund et al. 2003), NR1H3 (Laffitte et al. 2001b), as well as APOE (Laffitte et al. 2001a). With the exception of CETP, which was not expressed in the macaque $\mathrm{CL}$, our previous (Bogan et al. 2009) and current findings are consistent with an activation of $\mathrm{NR} 1 \mathrm{H} 2$ and $\mathrm{NR} 1 \mathrm{H} 3$ in the primate $\mathrm{CL}$ near the time of functional regression based on increased ABCA1, ABCG1, PLTP, NR1H3, and APOE mRNA levels.

This report is the first to detail the presence of components necessary for a functional RCT system in the $\mathrm{CL}$ of any species. The only other report on the RCT system that is relevant to the CL came from studies utilizing luteinizing granulosa cells obtained from women undergoing IVF (Drouineaud et al. 2007). In that study, synthetic $\mathrm{NR} 1 \mathrm{H} 2 / \mathrm{NR} 1 \mathrm{H} 3$ agonists

Figure 8 Rhesus macaque luteal cholesterol levels and cholesterol ester/lipid droplet localization prior to and following spontaneous functional regression. Panel A contains normalized cholesterol concentrations in $C L$ extracts from the early $(E)$, mid $(M)$, mid-late $(M L)$, functional late $(\mathrm{FL})$, functionally regressed late $(\mathrm{FRL})$, and very late $(\mathrm{VL})$ stages of the luteal phase. Error bars indicate one s.E.M. Columns with different letters of the same case are significantly different $(P<0.05)$. Representative lipid droplet staining and localization results, as determined by confocal microscopy, are presented in panel B for the mid and functionally regressed late stages. Actin is represented by blue fluorescence, nuclei are red, and neutral lipids including cholesterol esters are green. The inset in the mid $400 \times$ lipid overlay is a parallel section that was extracted with methanol to remove all lipids

(background control). The approximate locations of various cell types are indicated in the first image for each stage and include: large luteal cells (L); small luteal or stromal cells (S); and blood vessels (V).

The scale bar in the lower right hand corner of each image is $50 \mu \mathrm{m}$. 
inhibited $\mathrm{P}_{4}$ synthesis while stimulating mRNA expression of ABCA1, ABCG1, APOE, PLTP, and NR1H3 (Drouineaud et al. 2007). In the present study, expression of all components necessary for a functional RCT system was found within the macaque $\mathrm{CL}$, and particularly within large luteal cells, including cholesterol sensors $(\mathrm{NR} 1 \mathrm{H} 2$ and $\mathrm{NR} 1 \mathrm{H} 3)$, cholesterol efflux proteins (ABCA1 and ABCG1), cholesterol acceptors (APOA 1 and APOE), as well as plasma proteins critical for HDL maturation (LCAT and PLTP). The mRNA and/or protein levels of known NR1H2/NR1H3 target genes underwent dynamic changes near the time of functional regression in the macaque $\mathrm{CL}$ consistent with an induction of these receptors and consequently RCT during this period. It seems logical that an induction of RCTactivity in the CL could deplete cholesterol stores and subsequently inhibit $\mathrm{P}_{4}$ synthesis. Surprisingly, however, cholesterol concentrations in luteal homogenates increased throughout the luteal phase including the period of functional regression. Analysis of lipid droplets within luteal tissue indicated that clear differences in cholesterol ester/lipid storage or localization had occurred between fully functional (mid CL) and functionally regressed late $\mathrm{CL}$. Following functional regression, droplets that were noticeably larger compared to mid $\mathrm{CL}$ were present, with some appearing to reside in the extracellular space. Thus, cholesterol appears to be sequestered from the steroidogenic machinery in the form of these large droplets, but is not necessarily completely removed or cleared from the tissue. Collectively, these results indicate that the RCT system may be induced in the primate $C L$ near the time of functional regression, and consequently, may play an integral role in the cessation of $\mathrm{P}_{4}$ synthesis and ultimately luteolysis. Future studies are needed to further define the functional importance of the RCT system in the primate CL.

\section{Materials and Methods}

\section{CL collection}

All animal protocols were approved by the Oregon National Primate Research Center's Institutional Animal Care and Use Committee. Regularly cycling female rhesus macaques between 5 and 10 years of age were used for these studies. The care and handling of rhesus macaques was performed as described previously (Wolf et al. 1990). CL collected between days 10-12 (mid-late stage), 14-16 (late stage), and 18-19 (very late stage) after the midcycle LH surge were used for analysis as these stages encompass the periods immediately preceding functional regression (mid-late stage), during functional regression (late stage), and structural regression (very late stage, menses). The late stage $\mathrm{CL}$ were further divided into two groups ( $n=4 \mathrm{CL}$ /group) based on serum concentrations of $\mathrm{P}_{4}$ with $\mathrm{CL}$ from animals maintaining high serum levels of $\mathrm{P}_{4}(5.4 \pm 1.2 \mathrm{ng} / \mathrm{ml})$ considered to be functional late stage $C L$, and $C L$ from animals having low serum levels of $P_{4}$ $(0.4 \pm 0.1 \mathrm{ng} / \mathrm{ml})$ considered to be functionally-regressed late stage $\mathrm{CL}$ as described previously (Bogan et al. 2009). In some cases, $C L$ collected between days $3-5$ (early stage, developing $\mathrm{CL}$ ) and $7-8$ (mid stage, fully functional $\mathrm{CL}$ ) were also included in the analyses.

\section{mRNA quantification by microarray and Taqman Q-PCR analyses}

Microarray expression data were obtained using raw fluorescence intensity files (.cel files) from two previously published microarray experiments (Bogan et al. 2008a, 2009) that are accessible through the NCBI GEO database (accession numbers GSE10367 and GSE12807; http://www.ncbi.nlm. nih.gov/geo/). The raw expression intensities corresponding to early, mid, mid-late, and very late stages (Bogan et al. 2008a), as well as functional and functionally regressed late stages (Bogan et al. 2009) were normalized by the robust multichip average algorithm (Irizarry et al. 2003) using Affymetrix Expression Console version 1.0 software. Probe sets corresponding to APOA1, APOE, LCAT, PLTP, CETP, NR1H2, and $\mathrm{NR} 1 \mathrm{H} 3$ were located (http://www.affymetrix.com/analysis/ index.affx) and used to isolate their expression data from the newly generated microarray expression database.

To determine whether or not a gene was expressed in the macaque $\mathrm{CL}$, a database containing GCOS absolute expression analysis data was referenced. This database was developed by the Affymetrix Microarray Core of the Oregon Health \& Science University Gene Microarray Shared Resource. For each individual GeneChip genome array hybridization performed as part of two previous microarray projects (Bogan et al. 2008a, 2009), a GCOS absolute expression analysis was performed on nonnormalized data with parameters $\alpha_{1}$ and $\alpha_{2}$ set to 0.05 and 0.065 (Affymetrix defaults) respectively. These parameters determine whether a transcript is detected and therefore present $(\mathrm{P})(P \leq 0.05)$, marginally detected $(P=0.051-0.065)$, or not detected and thus considered not to be expressed within the $\mathrm{CL}(P>0.065)$.

Q-PCR was performed as described previously (Bogan et al. 2008a) with the exception that target genes were normalized to mitochondrial ribosomal protein S10 (MRPS10). Primer and probe sequences used for Q-PCR analysis are provided in Table 1.

SQ-PCR was performed using CDNA generated from various rhesus macaque tissues. RT-PCR was performed using $1 \mu \mathrm{g}$ RNA, and the cDNA was diluted to a $100 \mu \mathrm{l}$ final volume as described elsewhere (Bogan et al. 2008a). Primers were designed using Vector NTI software (Informax, Inc., Bethesda, MD, USA) to amplify a region of 200-700 bps in length and were contained within regions of each gene that are homologous among all known transcript variants. Primer sequences and annealing temperatures used in the PCR reactions are provided in Table 1. PCR reactions utilized $6 \mu \mathrm{l}$ cDNA and $400 \mathrm{nM}$ gene-specific primers in a $30 \mu \mathrm{l}$ reaction. The reactions were stopped at three different cycle numbers to allow collection of $10 \mu \mathrm{l}$ aliquots. After addition of $5 \times$ nucleic acid-loading buffer (Bio-Rad), $5 \mu \mathrm{l}$ PCR product $(10 \mu \mathrm{l}$ for $\mathrm{NR} 1 \mathrm{H} 2)$ was resolved by $1 \%$ agarose $(\mathrm{w} / \mathrm{v})$ gel electrophoresis. To estimate the linear range of amplification, PCR was performed using $C L C D N A$, and the reactions were terminated 
Table 1 Individual gene information for Q-PCR and SQ-PCR analyses.

\begin{tabular}{|c|c|c|c|}
\hline Gene symbol & Forward primer $\left(5^{\prime}-3^{\prime}\right)$ & Reverse primer $\left(5^{\prime}-3^{\prime}\right)$ & $\begin{array}{l}\text { Probe }\left(5^{\prime}-3^{\prime}\right) \text { : } 6 \text { FAM-sequence-MGBNFQ } \\
\text { MRPS10 only: VIC-sequence-MGBNFQ }\end{array}$ \\
\hline \multicolumn{4}{|c|}{ Q-PCR forward and reverse primers as well as MGB probe sequences } \\
\hline$A P O A 1$ & ACTCAAAGACAGCGGCAAAGA & GTCCCAGTTGTCCAGGAGCTT & ССТTСAАACTGGGACACATA \\
\hline$A P O E$ & CTGGGTGCAGACACTGTCTGA & GCTGTTCСTCСАGTTCCGATT & TCAACTCСТTCATGGTCTCA \\
\hline $\mathrm{NR} 1 \mathrm{H} 2$ & GGGAACTGGACTTTCGTCTCAA & GAAACATTTGCTGGGTGAATGTC & TCTCTAGAATGGTCAACCCAG \\
\hline $\mathrm{NR} 1 \mathrm{H} 3$ & TGTGCACGAATGACTGTTCTTTT & СССТTCTCAGTCTGTTCСACTTC & ATCCGGCCCAGAAAACAAAA \\
\hline MRPS10 & AATGTGCCCAACCTTCATGTC & TCCAGGCAAACTGTTCCTTCA & TGAAGGCCATGCAGTCTCTCAAGTCCC \\
\hline Gene symbol & Forward primer $\left(5^{\prime}-3^{\prime}\right)$ & Reverse primer $\left(5^{\prime}-3^{\prime}\right)$ & Annealing temperature $\left({ }^{\circ} \mathrm{C}\right)$ \\
\hline \multicolumn{4}{|c|}{ SQ-PCR forward and reverse primer sequences and annealing temperature used in PCR reaction } \\
\hline APOA1 & CCACGGСССТTCAGGATGAA & TCAGATGCTCGCTGGCCTTG & 64 \\
\hline$A P O E$ & GTCGCTTTTGGGATTACCTG & TGCTCСТTCACСТCGTCCAG & 53 \\
\hline $\mathrm{NR} 1 \mathrm{H} 2$ & TACAGGACAAGAAGCTACCG & ACATGCTCAATCAGGTTCAG & 55 \\
\hline $\mathrm{NR} 1 \mathrm{H} 3$ & CAGAGAGGAAGCCAGGATGC & CACTTGCGAAGCCGACACTC & 62 \\
\hline PPIA & CCAGGGTTTATGTGTCAGGG & TGССТTСТTТСАСТTТGССА & 56 \\
\hline
\end{tabular}

at 21, 24, 27, 30, 33, and 36 cycles. Based on these results (data not shown), SQ-PCR was performed on cDNA from 21 different tissues, and three different cycle numbers were attempted for each gene corresponding to mid-linear range, just prior to saturation, and post-saturation. Cyclophilin A (PPIA) was used as a housekeeping control.

\section{Western blot analysis}

Rabbit MABs produced against human antigens corresponding to SCARB1 (clone EP1556Y, catalog no. 1971), LDLR (clone EP1553Y, catalog no. 1956), and ABCG1 (clone EP1366Y, catalog no. 1945) were purchased from Epitomics, Inc. (Burlingame, CA, USA). Mouse MABs produced against human antigens were used for ABCA1 (clone AB.H10, catalog no. sc-58219, Santa Cruz Biotechnology, Santa Cruz, CA, USA) and NR1H3 (clone PPZ0412, catalog no. PP-PPZ0412, R\&D Systems, Minneapolis, MN, USA). A rabbit polyclonal antibody produced against human $\mathrm{NR} 1 \mathrm{H} 2$ was purchased from Aviva Systems Biology (San Diego, CA, USA; catalog no. ARP38906).

Either $12 \mu \mathrm{g}$ (ABCA1), $20 \mu \mathrm{g}$ (SCARB1 and NR1H2), $30 \mu \mathrm{g}(\mathrm{ABCG} 1$ and LDLR), or $50 \mu \mathrm{g}(\mathrm{NR} 1 \mathrm{H} 3)$ protein were loaded into individual wells. Antibodies were used at the following concentrations: anti-ABCA1, $0.2 \mu \mathrm{g} / \mathrm{ml}$; antiABCG1, $0.017 \mu \mathrm{g} / \mathrm{ml}$; anti- LDLR, $0.14 \mu \mathrm{g} / \mathrm{ml}$; anti-SCARB1, $0.027 \mu \mathrm{g} / \mathrm{ml}$; anti-NR1H2, $1 \mu \mathrm{g} / \mathrm{ml}$; anti-NR1H3, $1.25 \mu \mathrm{g} / \mathrm{ml}$. Protein levels from individual $\mathrm{CL}(n=4 \mathrm{CL} / \mathrm{stage})$ were normalized to $\beta$-tubulin (TUBB), and western blot procedures and subsequent densitometry analysis were performed as described previously (Bogan et al. 2008a, 2008b).

\section{Immunohistochemistry}

The anti-ABCG1, LDLR, SCARB1, NR1H2, and NR1H3 antibodies used in western blot analysis were also used for IHC. For ABCA1, a rabbit polyclonal antibody (catalog no. NB400-105) produced against human ABCA1 was purchased from Novus Biologicals, Inc. (Littleton, CO, USA). A rabbit polyclonal antibody against human APOE (catalog no. 1831) and rabbit MAB against human LCAT (clone EPR1384Y, catalog no. 2013) were purchased from Epitomics, Inc. A chicken polyclonal antibody produced against human APOA1 was purchased from GenWay Biotech, Inc. (San Diego, CA, USA; catalog no. 15-288-20069F), and a mouse MAB produced against human PLTP was from GeneTex, Inc. (Irvine, CA, USA; clone 2F3-G4, catalog no. GTX90539). Antibodies were used at the following concentrations: anti-ABCA1, $3 \mu \mathrm{g} / \mathrm{ml}$; antiABCG1, $0.33 \mu \mathrm{g} / \mathrm{ml}$; anti-LDLR, $0.875 \mu \mathrm{g} / \mathrm{ml}$; anti-SCARB1, $0.27 \mu \mathrm{g} / \mathrm{ml}$; anti-APOE, $0.46 \mu \mathrm{g} / \mathrm{ml}$; anti-APOA1, $2 \mu \mathrm{g} / \mathrm{ml}$; anti-LCAT, $0.19 \mu \mathrm{g} / \mathrm{ml}$; anti-PLTP, $5 \mu \mathrm{g} / \mathrm{ml}$; anti-NR1H2, $3 \mu \mathrm{g} / \mathrm{ml}$; anti-NR1H3, $20 \mu \mathrm{g} / \mathrm{ml}$. Specificity was determined by probing a $\mathrm{CL}$ section with primary antibody that had been pre-absorbed with its immunizing peptide if available (anti-ABCA1, ABCG1, LDLR, SCARB1, APOE, APOA1, and NR1H2), or the primary antibody was excluded if no peptide was available for preabsorption (anti-LCAT, PLTP, and NR1H3). CL sections from two to three animals per stage were analyzed for each antibody. IHC analysis and image capture were performed as described previously (Bogan et al. 2008b).

\section{Cholesterol quantification and localization}

Cholesterol was extracted according to a published protocol with minor modifications (McDonald et al. 2007). Briefly, frozen $\mathrm{CL}$ were homogenized in $3 \mathrm{ml}$ PBS followed by the addition of $6.6 \mathrm{ml}$ of a chloroform/methanol (1:1 v:v) solution, and were vortexed for $2 \mathrm{~min}$. Samples were centrifuged at $1400 \mathrm{~g}$ for $5 \mathrm{~min}$, and the lower organic layer was transferred to a new tube. Samples were dried under an air stream in a $37^{\circ} \mathrm{C}$ water bath and resuspended in $2 \mathrm{ml}$ toluene. The lipid extracts were run over a $100 \mathrm{mg}$ silica solid-phase extraction column (Biotage $A B$, Charlottesville, VA, USA) pre-conditioned with $2 \mathrm{ml}$ hexane and washed with $1 \mathrm{ml}$ hexane. Cholesterol was eluted with $8 \mathrm{ml}$ of $0.5 \%(\mathrm{v}: \mathrm{v})$ isopropanol in hexane, dried down, and resuspended in $500 \mu \mathrm{l}$ methanol. Cholesterol concentrations were determined using a fluorometric assay kit (Cayman Chemical Co., Ann Arbor, MI, USA) following the manufacturer's recommendations with slight modifications. A final volume of $1 \mu \mathrm{l}$ of all unknowns was used for the assay, and the methanol concentration was held constant at $1 \%$ in all unknowns and standards. Total cholesterol content was normalized to tissue weight. 
For lipid droplet analysis, fresh frozen CL collected at either the mid or functionally regressed late stages were cut in $10 \mu \mathrm{m}$ slices. Sections were fixed with $4 \%$ paraformaldehyde and $1 \%$ calcium chloride (w:v) in TBS for $10 \mathrm{~min}$ at room temperature, and washed in three changes of PBS. Sections were blocked for $30 \mathrm{~min}$ at room temperature with Image-iT Signal Enhancer (Invitrogen Co). Sections were stained with spectrally distinct fluorophores for actin (phalloidin-Alexa Fluor 350 conjugate, Invitrogen), nuclei (TO-PRO-3 iodide, Invitrogen), and neutral lipids including cholesterol esters (LipidTox, Invitrogen) following the manufacturer's recommendations. A negative control for neutral lipid fluorescence was included consisting of a section extracted with methanol for $15 \mathrm{~min}$ at room temperature. Slides were imaged using a Leica TCS SP spectral confocal imaging system.

\section{Statistical analyses}

Normalized microarray, Q-PCR, and western blot data were log transformed if necessary to stabilize variance. Data were analyzed using one-way ANOVA followed by pairwise comparisons with the Student-Newman-Keuls test, and differences were considered statistically significant at $P<0.05$.

\section{Declaration of interest}

The authors declare that there is no conflict of interest that could be perceived as prejudicing the impartiality of the research reported.

\section{Funding}

This work was supported by the following National Institutes of Health grants: U54 HD55744 (J D Hennebold), R01 HD42000 (J D Hennebold), RR00163 (J D Hennebold), and T32 training grant HD007133 (R L Bogan).

\section{Acknowledgements}

The authors would like to thank Dr Ov Slayden who provided the microscope and camera for capturing digital photomicrographs, as well as technical assistance on their use. The authors also would like to thank to Dr Marina Peluffo for assistance with confocal microscopy image capture, and Ms Melinda Murphy for general laboratory technical assistance. We would also like to thank the following core facilities at the Oregon National Primate Research Center: Molecular and Cellular Biology Core (Drs Eliot Spindel and Yibing Ja); and the Imaging and Morphology Core (Dr Anda Cornea and Ms Barbra Mason).

\section{References}

Bogan RL, Murphy MJ, Stouffer RL \& Hennebold JD 2008a Systematic determination of differential gene expression in the primate corpus luteum during the luteal phase of the menstrual cycle. Molecular Endocrinology 22 1260-1273.
Bogan RL, Murphy MJ, Stouffer RL \& Hennebold JD 2008b Prostaglandin synthesis, metabolism, and signaling potential in the rhesus macaque corpus luteum throughout the luteal phase of the menstrual cycle. Endocrinology 149 5861-5871.

Bogan RL, Murphy MJ \& Hennebold JD 2009 Dynamic changes in gene expression that occur during the period of spontaneous functional regression in the rhesus macaque corpus luteum. Endocrinology 150 1521-1529.

Brannian JD \& Stouffer RL 1991 Progesterone production by monkey luteal cell subpopulations at different stages of the menstrual cycle: changes in agonist responsiveness. Biology of Reproduction 44 141-149.

Cameron JL \& Stouffer RL 1982 Gonadotropin receptors of the primate corpus luteum. II. Changes in available luteinizing hormoneand chorionic gonadotropin-binding sites in macaque luteal membranes during the nonfertile menstrual cycle. Endocrinology 110 2068-2073.

Drouineaud V, Sagot P, Garrido C, Logette E, Deckert V, Gambert P, Jimenez C, Staels B, Lagrost L \& Masson D 2007 Inhibition of progesterone production in human luteinized granulosa cells treated with LXR agonists. Molecular Human Reproduction 13 373-379.

Duffy DM, Stewart DR \& Stouffer RL 1999 Titrating luteinizing hormone replacement to sustain the structure and function of the corpus luteum after gonadotropin-releasing hormone antagonist treatment in rhesus monkeys. Journal of Clinical Endocrinology and Metabolism 84 $342-349$.

Dullaart RP \& Van Tol A 2001 Role of phospholipid transfer protein and prebeta-high density lipoproteins in maintaining cholesterol efflux from Fu5AH cells to plasma from insulin-resistant subjects. Scandinavian Journal of Clinical and Laboratory Investigation 61 69-74.

Eyster KM, Ottobre JS \& Stouffer RL 1985 Adenylate cyclase in the corpus luteum of the rhesus monkey. III. Changes in basal and gonadotropinsensitive activities during the luteal phase of the menstrual cycle. Endocrinology 117 1571-1577.

Gelissen IC, Harris M, Rye KA, Quinn C, Brown AJ, Kockx M, Cartland S, Packianathan M, Kritharides L \& Jessup W 2006 ABCA1 and ABCG1 synergize to mediate cholesterol export to apoA-I. Arteriosclerosis, Thrombosis, and Vascular Biology 26 534-540.

Glass C, Pittman RC, Weinstein DB \& Steinberg D 1983 Dissociation of tissue uptake of cholesterol ester from that of apoprotein A-I of rat plasma high density lipoprotein: selective delivery of cholesterol ester to liver, adrenal, and gonad. PNAS 80 5435-5439.

Gwynne JT \& Strauss JF III 1982 The role of lipoproteins in steroidogenesis and cholesterol metabolism in steroidogenic glands. Endocrine Reviews 3 299-329.

Hoyer PB 1998 Regulation of luteal regression: the ewe as a model. Journal of the Society for Gynecologic Investigation 5 49-57.

Irizarry RA, Hobbs B, Collin F, Beazer-Barclay YD, Antonellis KJ, Scherf U \& Speed TP 2003 Exploration, normalization, and summaries of high density oligonucleotide array probe level data. Biostatistics 4 249-264.

Jonas A 2000 Lecithin cholesterol acyltransferase. Biochimica et Biophysica Acta 1529 245-256.

Kaminski WE, Piehler A \& Wenzel JJ 2006 ABC A-subfamily transporters: structure, function and disease. Biochimica et Biophysica Acta 1762 510-524.

Laffitte BA, Repa JJ, Joseph SB, Wilpitz DC, Kast HR, Mangelsdorf DJ \& Tontonoz P 2001a LXRs control lipid-inducible expression of the apolipoprotein $\mathrm{E}$ gene in macrophages and adipocytes. PNAS 98 507-512.

Laffitte BA, Joseph SB, Walczak R, Pei L, Wilpitz DC, Collins JL \& Tontonoz P $2001 b$ Autoregulation of the human liver $\mathrm{X}$ receptor alpha promoter. Molecular and Cellular Biology 21 7558-7568.

Lipsett MB 1978 Steroid hormones. In Reproductive Endocrinology, pp 80-92. Eds SC Yen \& RB Jaffe. Philadelphia: WB Saunders Press.

Lund EG, Menke JG \& Sparrow CP 2003 Liver X receptor agonists as potential therapeutic agents for dyslipidemia and atherosclerosis. Arteriosclerosis, Thrombosis, and Vascular Biology 23 1169-1177.

Mahley RW 1988 Apolipoprotein E: cholesterol transport protein with expanding role in cell biology. Science 240 622-630.

Mahley RW, Huang Y \& Weisgraber KH 2006 Putting cholesterol in its place: apoE and reverse cholesterol transport. Journal of Clinical Investigation 116 1226-1229. 
McDonald JG, Thompson BM, McCrum EC \& Russell DW 2007 Extraction and analysis of sterols in biological matrices by high performance liquid chromatography electrospray ionization mass spectrometry. Methods in Enzymology 432 145-170.

Neufeld EB, Remaley AT, Demosky SJ, Stonik JA, Cooney AM, Comly M, Dwyer NK, Zhang M, Blanchette-Mackie J, Santamarina-Fojo S et al. 2001 Cellular localization and trafficking of the human ABCA1 transporter. Journal of Biological Chemistry 276 27584-27590.

Niswender GD, Juengel JL, Silva PJ, Rollyson MK \& McIntush EW 2000 Mechanisms controlling the function and life span of the corpus luteum. Physiological Reviews 80 1-29.

Orso E, Broccardo C, Kaminski WE, Bottcher A, Liebisch G, Drobnik W, Gotz A, Chambenoit O, Diederich W, Langmann T et al. 2000 Transport of lipids from golgi to plasma membrane is defective in tangier disease patients and Abc1-deficient mice. Nature Genetics 24 192-196.

Reaven E, Chen YD, Spicher M \& Azhar S 1984 Morphological evidence that high density lipoproteins are not internalized by steroid-producing cells during in situ organ perfusion. Journal of Clinical Investigation $\mathbf{7 4}$ 1384-1397.

Repa JJ \& Mangelsdorf DJ 2000 The role of orphan nuclear receptors in the regulation of cholesterol homeostasis. Annual Review of Cell and Developmental Biology 16 459-481.

Santamarina-Fojo S, Remaley AT, Neufeld EB \& Brewer HB Jr 2001 Regulation and intracellular trafficking of the ABCA1 transporter. Journal of Lipid Research 42 1339-1345.

Stouffer RL 2003 Progesterone as a mediator of gonadotrophin action in the corpus luteum: beyond steroidogenesis. Human Reproduction Update 9 99-117.

Stouffer RL 2006 Structure, function, and regulation of the corpus luteum. In The Physiology of Reproduction, edn 3, pp 475-526. Eds E Knobil \& JD Neill. New York: Raven Press.

Tanaka AR, Abe-Dohmae S, Ohnishi T, Aoki R, Morinaga G, Okuhira K, Ikeda Y, Kano F, Matsuo M, Kioka N et al. 2003 Effects of mutations of ABCA1 in the first extracellular domain on subcellular trafficking and ATP binding/hydrolysis. Journal of Biological Chemistry 278 8815-8819.
Von Eckardstein A, Jauhiainen M, Huang Y, Metso J, Langer C, Pussinen P, Wu S, Ehnholm C \& Assmann G 1996 Phospholipid transfer protein mediated conversion of high density lipoproteins generates pre beta 1-HDL. Biochimica et Biophysica Acta 1301 255-262.

Wang N, Ranalletta M, Matsuura F, Peng F \& Tall AR 2006 LXR-induced redistribution of $A B C G 1$ to plasma membrane in macrophages enhances cholesterol mass efflux to HDL. Arteriosclerosis, Thrombosis, and Vascular Biology 26 1310-1316.

Wang X, Collins HL, Ranalletta M, Fuki IV, Billheimer JT, Rothblat GH, Tall AR \& Rader DJ 2007 Macrophage ABCA1 and ABCG1, but not SR-BI, promote macrophage reverse cholesterol transport in vivo. Journal of Clinical Investigation 117 2216-2224.

Wojcicka G, Jamroz-Wisniewska A, Horoszewicz K \& Beltowski J 2007 Liver $X$ receptors (LXRs). Part I: structure, function, regulation of activity, and role in lipid metabolism. Postepy Higieny I Medycyny Doswiadczalnej 61 736-759.

Wolf DP, Thomson JA, Zelinski-Wooten MB \& Stouffer RL 1990 In vitro fertilization-embryo transfer in nonhuman primates: the technique and its applications. Molecular Reproduction and Development 27 261-280.

Yokoyama S 2006 Assembly of high-density lipoprotein. Arteriosclerosis, Thrombosis, and Vascular Biology 26 20-27.

Zaiou M, Arnold KS, Newhouse YM, Innerarity TL, Weisgraber KH, Segall ML, Phillips MC \& Lund-Katz S 2000 Apolipoprotein E - low density lipoprotein receptor interaction. Influences of basic residue and amphipathic alpha-helix organization in the ligand. Journal of Lipid Research 41 1087-1095.

Received 6 January 2009

First decision 18 February 2009

Revised manuscript received 24 August 2009

Accepted 22 September 2009 